Research Article

\title{
Integrated Management Software for Factory Production of Modular Buildings
}

\author{
SungHoon Nam (D), DooYong Lee, BongHo Cho ${ }^{\mathbb{D}}$, and KyungRai Kim \\ Department of Architectural Engineering, Ajou University, Gyeonggi-do, Suwon-si, Yeongtong-gu, \\ Woldeukeom-ro, 206, Republic of Korea \\ Correspondence should be addressed to KyungRai Kim; kyungrai@ajou.ac.kr
}

Received 4 December 2018; Accepted 17 April 2019; Published 6 May 2019

Academic Editor: Hossein Moayedi

Copyright (c) 2019 SungHoon Nam et al. This is an open access article distributed under the Creative Commons Attribution License, which permits unrestricted use, distribution, and reproduction in any medium, provided the original work is properly cited.

\begin{abstract}
After the first modular construction project in Korea in 2003, the scope and demand for modular systems have gradually increased. However, modular producers in Korea utilize spreadsheets to manage the process, manpower, and materials required for modular construction. This is inadequate compared to other countries that are more advanced in modular construction such as Japan and the United Kingdom. The management system in Korea decreases the effectiveness of modular construction in reducing construction time and cost. There is no formal system for managing modular production in Korea. Although some construction management programs utilized in the traditional construction industry are available, they do not reflect the flow of modular production, that is, to simultaneously produce several types of modules in accordance with demand in a factory. This research develops a modular-construction-specific production management system that has three overall functions: factory setup, project creation, and result analysis. These functions can link all the relevant data for managing modular production and can help manage several types of modules. The production management system is verified through simulation of the existing processes observed for a completed project and comparing the results to an alternative process. Through such comparisons, an optimized process design can be achieved.
\end{abstract}

\section{Introduction}

Recently, the construction industry has experienced a paradigm shift from a site-centered, labor-intensive industry to a mechanized, automated, and information-technologydependent industry [1]. In Korea, such changes are further accelerated by the reduction in construction industry workforce and by an aging workforce. These changes have pushed the construction industry to adopt a manufacturing industry production system of component production, component assembly, and provision for the finished product. Applied to the construction industry, the equivalent process involves the production of a house component (in a factory), the assembly of the house component (in a factory and on-site), and provision for the finished house [1]. This is a modular construction system, with a process that consists of the factory production, delivery, and assembly [2].
Interest for local and international modular housing systems is driven by the automation of the construction industry, and domestic companies and research centers are now increasingly studying and developing modular systems. After the first modular construction project for the Singi Elementary School in Korea in 2003, the scope and demand for modular systems have gradually increased. Modular systems refer to houses or buildings that are constructed by erecting a frame from steel, wood, and/or concrete (module) at an offsite location and completing the internal and external finishing on-site [3]. The majority of the work for buildings utilizing modular systems is performed in factories. The merits of modular systems include shortened building construction time and significant cost savings $[4,5]$. However, modular system construction is still in its nascent stage in Korea; hence, it is difficult to manage productivity and secure economic feasibility [6]. According to 
documentation related to production provided by these modular producers, Koreans utilize spreadsheets to manage the process, manpower, and material logistics. This is inadequate compared to modular construction management in countries such as Japan and the United Kingdom.

Studies related to improving modular system production have been performed by other researchers [7-13]. However, it is difficult to apply their findings to Korean factories owing to the different criteria in production, productivity, manpower, material, and laws. Therefore, the modular system of manufacturing process in Korea should be examined.

The objective of this research was to examine the manufacturing process for the completed JinjuHamyang build-transfer-lease (Build-Transfer-Lease) project and to analyze problems with the existing factory processes. The input and output data such as manpower, time, materials, and productivity were determined, and the framework for the software program was established based on the analyzed data. The input data related to the modular construction of the Jinju-Hamyang BTL project was applied to this developed program. Moreover, using the developed program, the optimized process was simulated by evaluating different conditions, such as manpower and time, from the existing process. Finally, the productivity results of the existing process were compared to the optimized process. Figure 1 depicts a flow chart of the research study.

\section{Materials and Methods}

2.1. Observed Modular Factory Manufacturing Process. We monitored and analyzed the current factory manufacturing processes for a private investment facility project for the Korean military constructed by a local modular construction company. The first monitoring period was from July 8 to July 9, 2015, and the second was performed on July 21,2015 . The project was then authorized by the Ministry of National Defense. The entire construction project covered two regions for the air force (Jinju) and two regions for the army (Hamyang and Yeosu). However, the modular systems were only constructed in the two regions for the army. The overall project duration was 105 days from June 3 to September 15, 2015, but the modular manufacturing period for the required 288 units was only 55 days [14].

The factory manufacturing process observed during the monitoring periods, with corresponding photos (Figure 2), were as follows: (a) Manufacturing of the floor frame is performed outside of the factory owing to limited space inside the factory and to make concrete pouring and transportation easy. In order to reduce errors and maintain the dimensional accuracy of the products, a rectangular jig is utilized for the floor steel frame. (b) The deck plate and wire mesh are installed on the floor frame, and concrete is poured to create the floor slab. (c) The concrete floor slab is positioned inside the factory, then the short-span frame, longspan frame, and ceiling frame are assembled. (d) Lightweight steel structures are assembled and installed, along with the inner wall panels and window frames. (e) Plumbing pipes, electrical equipment, and electrical wiring are

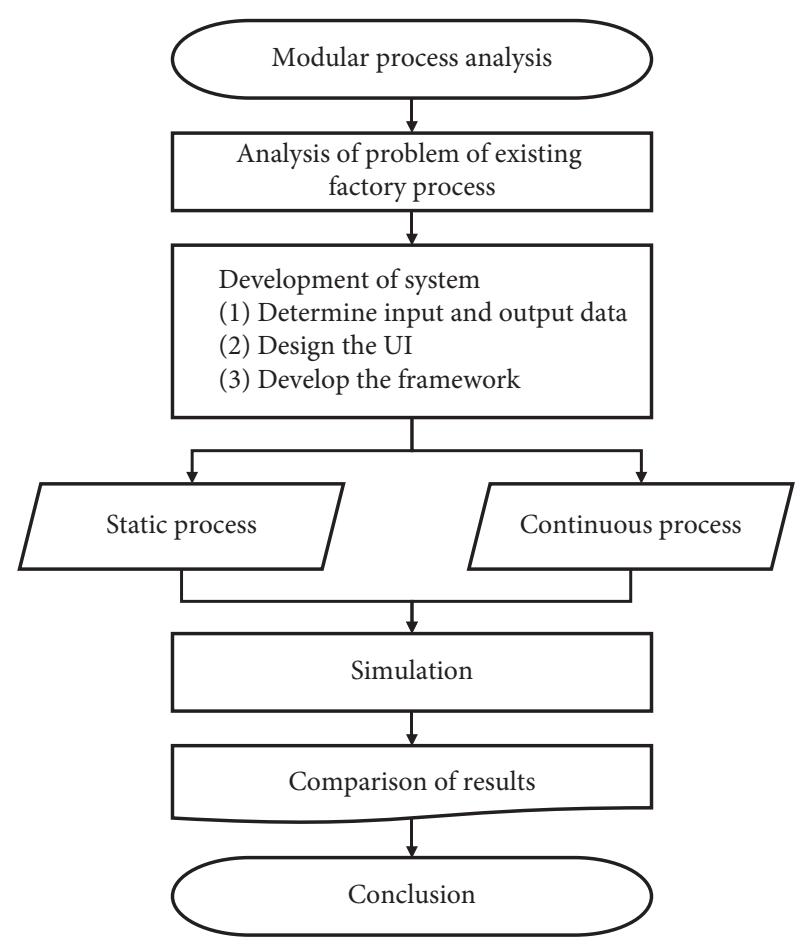

FIgURe 1: Research flow chart.

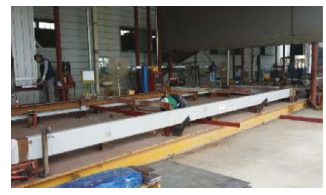

(a)

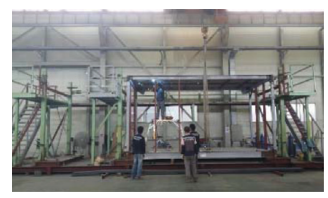

(c)



(e)



(g)

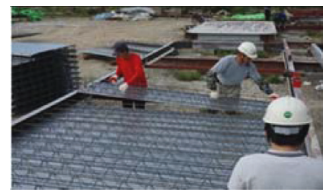

(b)



(d)

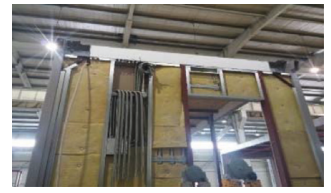

(f)

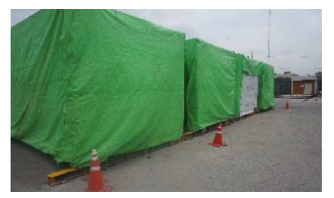

FIgURE 2: Factory manufacturing process. (a) Manufacturing of the floor frame. (b) Manufacturing of the concrete floor slab. (c) Assembly of the structural frame. (d) Installation of light-weight steel structures. (e) Installation of plumbing and electrical equipment. (f) Installation of inner walls and insulation. (g) External work and open storage. 
assembled in advance and installed. (f) Insulation is inserted between the light-weight steel structures and the inner wall panels. (g) The external wall panels are installed, and the module is placed outside and covered with waterproof wrappings until transportation because of space constraints inside the factory.

\subsection{Issues in Korean Modular Factory Manufacturing Process.} By monitoring the modular factory manufacturing process in Korea, we were able to identify that the entire process was being delayed owing to inefficient management. In particular, the manufacturing durations were not uniform, resulting in specific processes being delayed, which in turn delayed the entire process. The delays were caused by inefficient manpower allocation. Ideally, once a single process concludes, the workers proceed to the next process. However, it was observed that workers from the previous process who were unable to finish their work before being scheduled for the next process continued into the time allocated for the following process. This prevented the workers in the following process from starting their work on time. Kim et al. [1] and Kim et al. [15] observed the same problem, referred to as a bottleneck or congestion of work. This bottleneck is cited as a major problem in the modular process in other studies $[9,16,17]$.

Generally, to reduce the required construction time, more manpower and equipment can be added at a typical construction site. However, increasing manpower and equipment for factory manufacturing can have adverse effects owing to overlapping manpower, bottlenecks, and rework. Therefore, unlike on-site work, subassembly lines need to be added and optimized in the factory, and the construction period can be reduced by increasing manpower in conjunction with integration and subdivision of work. However, there is currently no analytical tool for predicting the effect of implementing a method for reducing construction time or for optimizing this method.

2.3. Process Categorization and Subdivision. Factory manufacturing processes are broadly categorized in three stages: (1) prestation stage, where the individual modular components are formed; (2) station stage, where the module is assembled and manufactured while moving along a rail; (3) poststation stage, where the completed modular unit is packaged and prepared for transport. The prestation stage can be distinguished by floor, wall, ceiling, and structure assembly activities. The station stage is where work is carried out in a continuous manner; hence, it is distinguished by subprocesses that occur sequentially. Finally, the poststation phase is subdivided into water-related processes and packaging process (Figure 3).

The work, work time, and number of workers per process are arranged as shown in Table 1 . The total work time was calculated by multiplying the work time per process with the manpower. The total work time was 5,710 minutes, including the manpower standby time. This time excludes the two days needed for curing the concrete in the floor slab.

\subsection{Integrated Management System Software}

2.4.1. Software Framework. The system developed for analyzing the modular factory manufacturing process in this study is referred to as the integrated management system, and it is equipped with three broad functions, as shown in Figure 4: factory setup, project creation, and results analysis. In the factory setup function, the modular manufacturing factory area and layout can be arranged. In the project creation function, the type, number of units, and manufacturing commencement date are set, and each module process type and associated manpower and material data are configured. In the results analysis function, alternative comparisons are made using the productivity index and record management based on the calculations using data from the project creation function. Moreover, data can be exported to a file using the output function.

2.4.2. Factory Setup Function. The factory length and width are configured through the workspace creation function, as shown in Figure 5. Then, the height of the factory is entered. It is possible to arrange the factory by applying a rotation angle from the initially drawn building corner. There is a function to set up the entrance and exit for materials to the factory and the location of the overhead crane. The process is set up in accordance with the workspace, factory size, and project characteristics at the time when the new factory is constructed (Figure 6). In the case of an existing factory, the setup function is intended to check whether the process can be applied when the existing manufacturing process is changed.

2.4.3. Project Creation Function. The detailed manufacturing line setup function allows the input of relevant information for configuration. The location, length, and rotation angle of the line can be established similar to the factory setup. The workspace area and free space that will be utilized to manufacture the modular unit can be set in this stage.

Additionally, when configuring the manufacturing line, the default setting is static production, but this can be changed to continuous production. For static production, since space is required for materials to be transported and for manpower to carry out operations, the width of the workspace and moving space need to be configured. Since the module moves along a rail in continuous production, there is a limitation in the workspace and the moving space for manpower. Therefore, they need to be set up in accordance with their respective requisite characteristics.

Finally, once the manufacturing line is set up, the manufacturing process is input (Figure 7). The breakdown information details for manpower and material are entered for each process. Breakdown information allows the input of the material name, specification, unit, quantity, and unit price, which are saved in the database (Figure 8). The breakdown information can be retrieved by utilizing the database.

2.4.4. Results Analysis Function. The results analysis function can calculate and show the daily work hours, weekly 




PS: Prestation, S: Station, OS: Outsourcing, M: Member, A: assembly, F: Floor, W: Wall, C: Celling, MA: Modular Assembly, WP: Wet Process, EP : End Process

FIGURE 3: Subdivided manufacturing process flow.

TABLE 1: Work, work time, and number of workers per process.

\begin{tabular}{|c|c|c|c|c|c|}
\hline Category & Process & Precedence & Work description & Time (min) & No. of workers \\
\hline \multirow{11}{*}{ Prestation } & PS-OS-2 & - & Processing of beam \& column member & 60 & 3 \\
\hline & PS-M-1 & - & Processing of plate/bracket & 60 & 1 \\
\hline & PS-M-2 & $\begin{array}{l}\text { PS-OS-1 } \\
\text { PS-OS-2 }\end{array}$ & Welding of column framework with plate/bracket & 60 & 1 \\
\hline & PS-A-F-1 & $\begin{array}{l}\text { PS-OS-1 } \\
\text { PS-M-1 }\end{array}$ & Painting and curing of beam/column framework & 180 & 2 \\
\hline & PS-A-F-2 & PS-M-2 & $\begin{array}{c}\text { Welding of floor slab material and assembly of floor } \\
\text { frame }\end{array}$ & 120 & 2 \\
\hline & PS-A-F-3 & PS-A-F-1 & Installation of deck and wire mesh & 60 & 3 \\
\hline & PS-A-W-1 & PS-A-F-2 & Pouring concrete in the floor frame & 60 & 2 \\
\hline & PS-A-C-1 & PS-M-2 & $\begin{array}{c}\text { Manufacturing of short-span outer wall (welding/ } \\
\text { bolting) }\end{array}$ & 15 & 2 \\
\hline & PS-A-C-2 & - & Manufacturing of plumbing/electrical wiring & $120^{*}$ & 2 \\
\hline & PS-MA-1 & $\begin{array}{l}\text { PS-M-2 } \\
\text { PS-A-C-1 } \\
\text { PS-A-F-3 }\end{array}$ & Manufacturing of ceiling frame (welding/bolting) & $120^{*}$ & 4 \\
\hline & PS-MA-2 & $\begin{array}{l}\text { PS-A-W-1 } \\
\text { PS-A-C-2 }\end{array}$ & Assembly of module frames and installation of brace & $120^{*}$ & 1 \\
\hline \multirow{11}{*}{ Station } & S-1 & PS-MA-1 & $\begin{array}{l}\text { Regular welding of modular unit and repair of } \\
\text { fireproof painting }\end{array}$ & 130 & 2 \\
\hline & S-2 & PS-MA-2 & Installation of runner and stud & $120^{*}$ & 2 \\
\hline & S-3 & S-1 & $\begin{array}{l}\text { Installation of gypsum board/insulation and } \\
\text { embedded plumbing pipe at long span }\end{array}$ & $90^{*}$ & 2 \\
\hline & S-4 & S-2 & $\begin{array}{l}\text { Installation of gypsum board/insulation and internal } \\
\text { stud at short span }\end{array}$ & $90^{*}$ & 2 \\
\hline & S-5 & S-3 & $\begin{array}{l}\text { Installation of vertical plumbing pipe, inner } \\
\text { insulation, and } \mathrm{A} / \mathrm{C} \text { box }\end{array}$ & $120^{*}$ & 2 \\
\hline & S-6 & S-4 & $\begin{array}{c}\text { Installation of inner gypsum board, Tyvek, and } \\
\text { electrical outlet }\end{array}$ & $80^{*}$ & 2 \\
\hline & S-7 & S-5 & Installation of windows and doors & $50^{*}$ & 2 \\
\hline & S-8 & $\begin{array}{l}\text { S-6 } \\
\text { S-S-1 }\end{array}$ & $\begin{array}{c}\text { Installation of external wall frame, installation } \\
\text { parallel sliding door, and arrangement of electric } \\
\text { conduit }\end{array}$ & $120^{*}$ & 2 \\
\hline & S-9 & S-7 & Installation of ceiling support & $120^{*}$ & 2 \\
\hline & S-10 & S-8 & Installation of ceiling gypsum board & 130 & 2 \\
\hline & S-S-1 & S-9 & Other finish work and transportation & $120^{*}$ & 1 \\
\hline
\end{tabular}


TABLE 1: Continued.

\begin{tabular}{|c|c|c|c|c|c|}
\hline Category & Process & Precedence & Work description & Time $(\min )$ & No. of workers \\
\hline \multirow{7}{*}{ Poststation } & WP-1 & - & $\begin{array}{c}\text { Manufacturing of external panel frame using jig and } \\
\text { installation of external materials }\end{array}$ & 60 & 1 \\
\hline & WP-2 & S-10 & $\begin{array}{l}\text { Apply urethane waterproofing in bathroom and } \\
\text { installation of buffer material }\end{array}$ & 30 & 2 \\
\hline & WP-3 & WP-1 & $\begin{array}{l}\text { Pouring and curing of autoclaved light-weight } \\
\text { concrete }\end{array}$ & 90 & 1 \\
\hline & WP-4 & WP-2 & $\begin{array}{l}\text { Installation of bathroom wall/floor tiles and } \\
\text { installation of ceiling panels }\end{array}$ & 60 & 1 \\
\hline & WP-5 & WP-3 & $\begin{array}{l}\text { Installation of bathroom ceramics (toilet bowl, water } \\
\text { basin, and mirror) and electrical outlet/switch/light }\end{array}$ & 30 & 3 \\
\hline & EP-1 & WP-4 & $\begin{array}{l}\text { Installation of finishing materials on bathroom floor, } \\
\text { baseboard, and ceiling molding/finishing materials }\end{array}$ & 240 & 1 \\
\hline & EP-2 & $\begin{array}{c}\text { S-10 } \\
\text { WP-5 }\end{array}$ & $\begin{array}{l}\text { Installation of bathroom light and furnishings and } \\
\text { quality inspection }\end{array}$ & 60 & 4 \\
\hline \multicolumn{3}{|c|}{ Manpower $*$ total hours } & \multicolumn{3}{|c|}{$\begin{array}{l}5,710 \text { minutes (including the manpower standby time (total } 580 \text { minutes) marked with a } \\
\operatorname{star}\left({ }^{*}\right) \text { in the process) }\end{array}$} \\
\hline
\end{tabular}



FIGURE 4: Software framework.

work days, process, manufacturing method, module output (calculated per day, week, month, and year), and manpower inputs based on the entered data. Moreover, a productivity comparison between alternative processes and the existing process is possible for evaluating any improvement from the existing process. Additionally, the factory layout setup can be saved in DWG format.

\section{Results and Discussion}

The information collected from monitoring the JinjuHamyang BTL construction project was applied to the program (Figure 9). A total of thirty modules were planned for manufacturing. Ten modules classified as wet process types, such as bathrooms (Type A), and twenty modules that did not require an additional wet process (Type B) were added.

The existing process created through the program and the optimized process integrating the manpower rearrangement and process were compared using the productivity index. The standard for changing the existing process was accelerated using manpower input for the process type on the critical path. The required time was standardized by changing the manpower input and work integration of the process type that were assigned to the continuous production line. Moreover, when a fixed daily workforce was required (i.e., when there is a minimum daily 


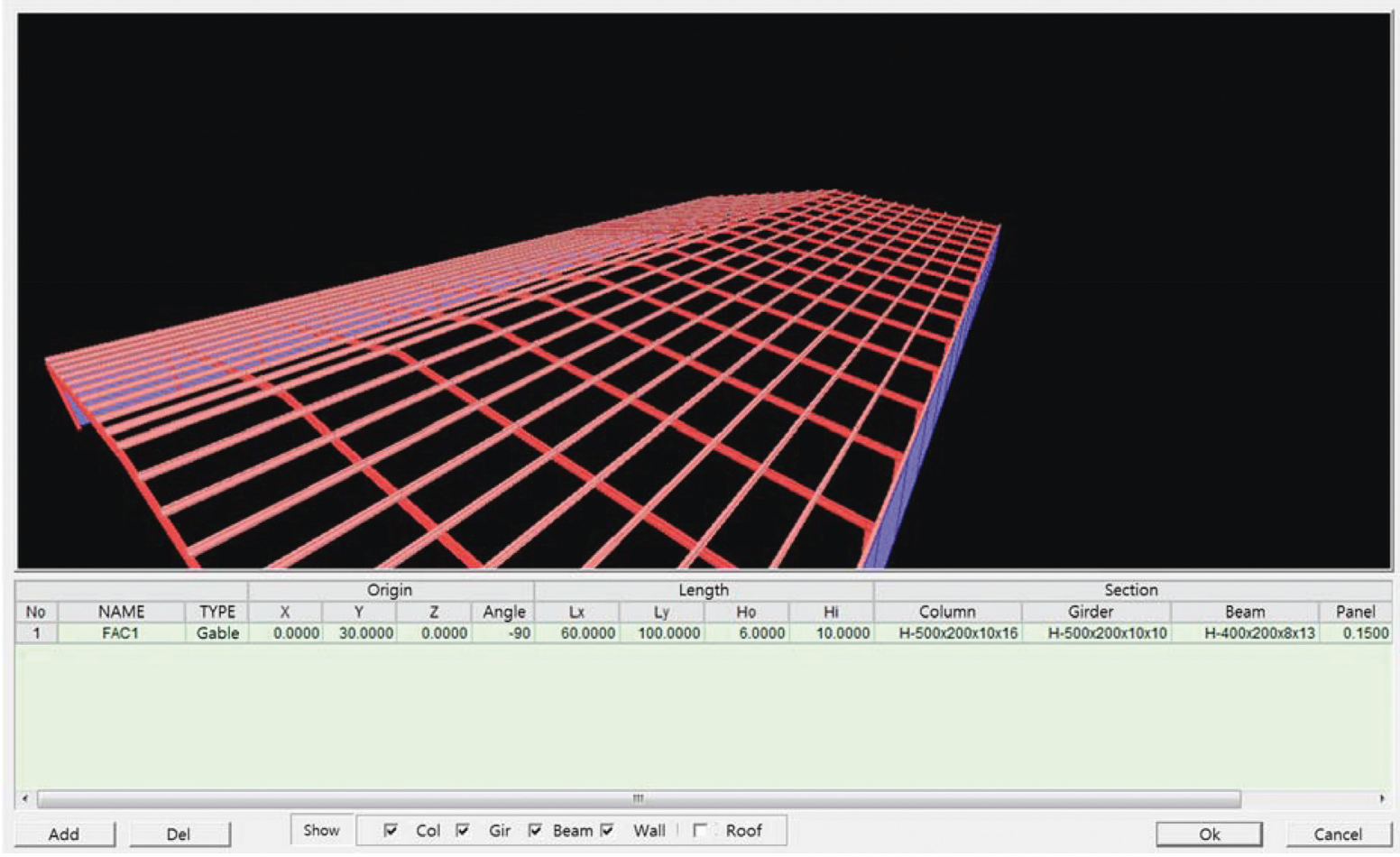

FIGURE 5: Roof frame after configuring the factory size.

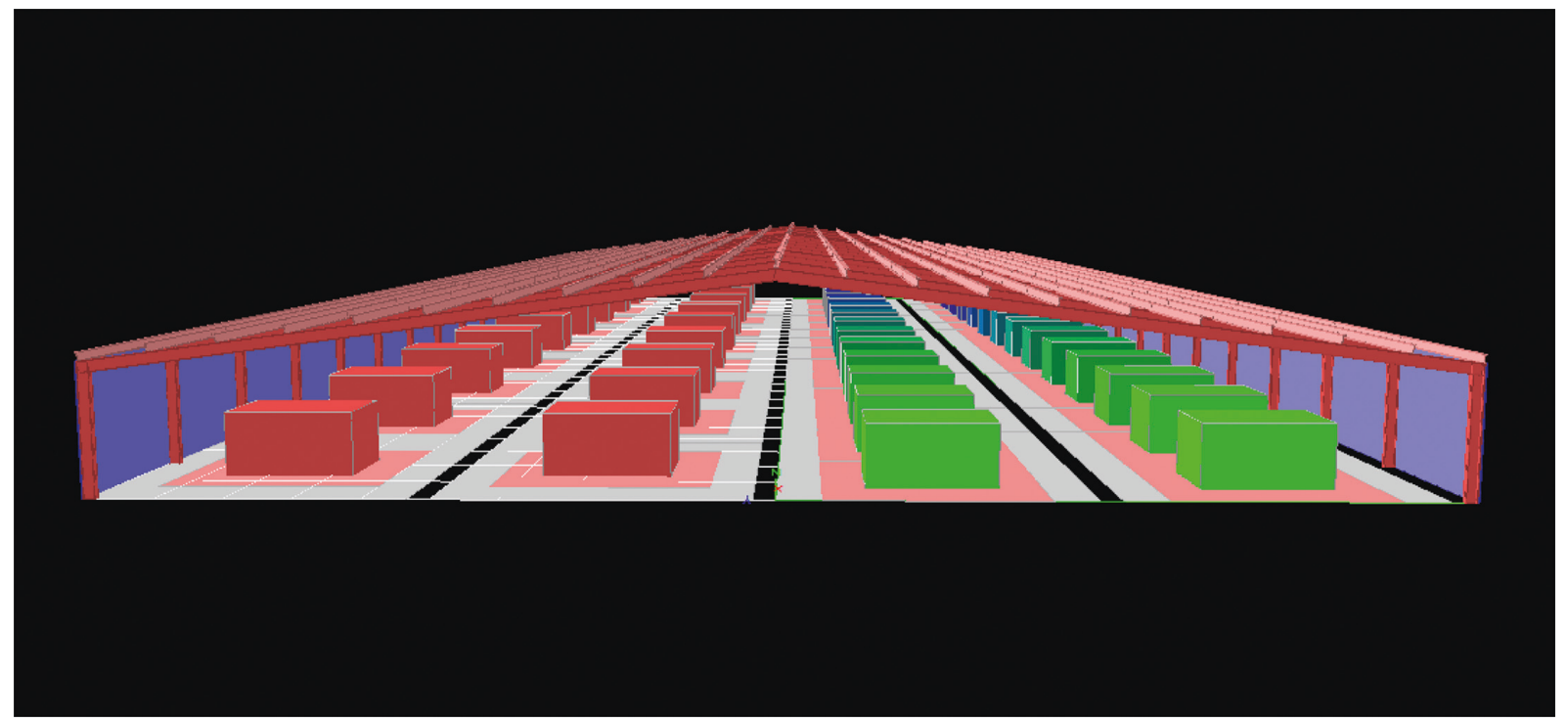

FIgURE 6: Process line after configuring the workspace and arranging the process line.

workforce), the daily average manpower input was lowered so that the spare time could be utilized to the extent that the process type on the critical path was not greatly changed.

Table 2 lists the comparison between existing and optimized processes. For optimization of the process, standby time in the existing process should be removed. Therefore, for the prestation stage, to standardize the required time per process to $60 \mathrm{~min}$, manpower was increased in the PS-A-F-1, PS-A-F-2, PS-MA-1, and PS-MA-2 processes. Moreover, to maximize the utilization of spare time, manpower for PS-A-
C-2 was reduced. In the station stage, to standardize the time spent on processes from S-1 to S-10 except S-6 and S-7, manpower was increased. Moreover, S-6 and S-7 were integrated to standardize the process time. In the poststation, additional manpower was input to the EP-1 process to reduce process time. For example, the time for the EP-1 process changed from 240 minutes to 60 minutes. As a result of the analysis, if the manufacturing times calculated by multiplying manpower input by time were compared, the existing manufacturing process required 5,710 minutes, and 


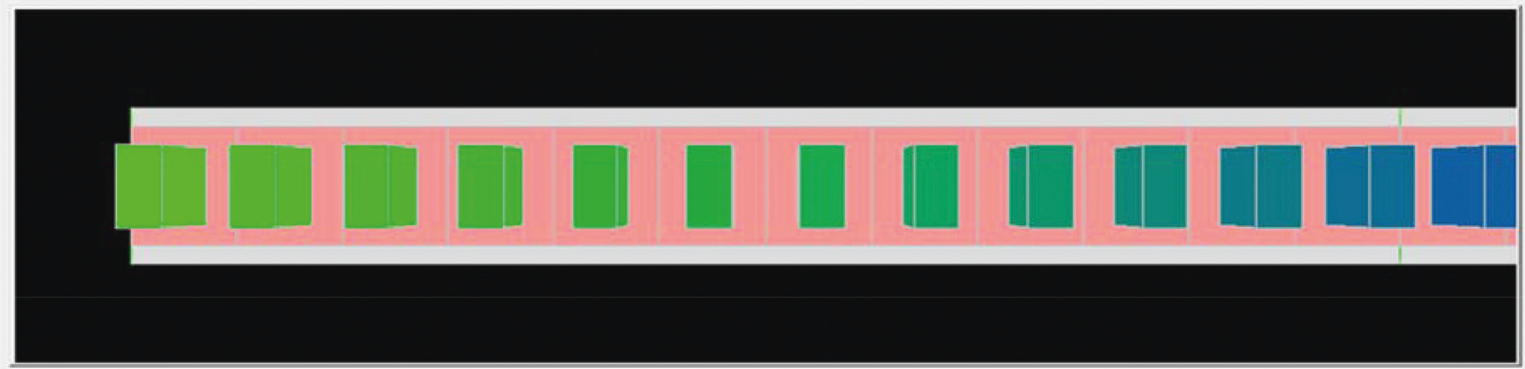



FIgURE 7: Manufacturing line with process code, process name, and time for continuous production line.

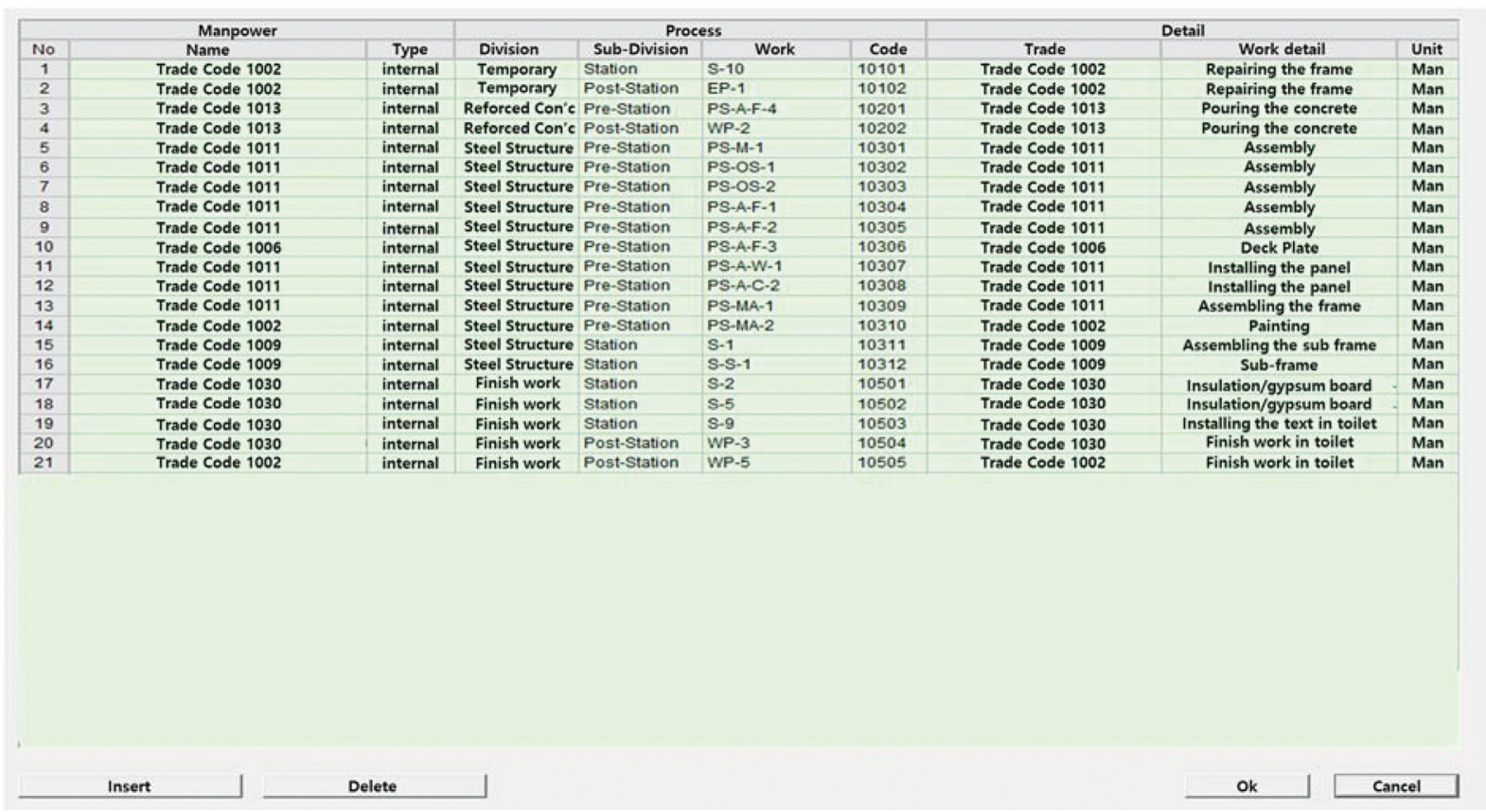

FIGURE 8: Manpower breakdown sheet.

the updated manufacturing process required 5,070 minutes. This is a $11.2 \%$ reduction in manufacturing time when the optimized process is used. If the comparison is made using the program alternative comparison function, the result is as shown in Table 3 and Figure 10.

\section{Conclusions}

We analyzed the process data collected from monitoring an existing modular manufacturing project and subdivided it into 31 processes. We then arranged the manpower, work 


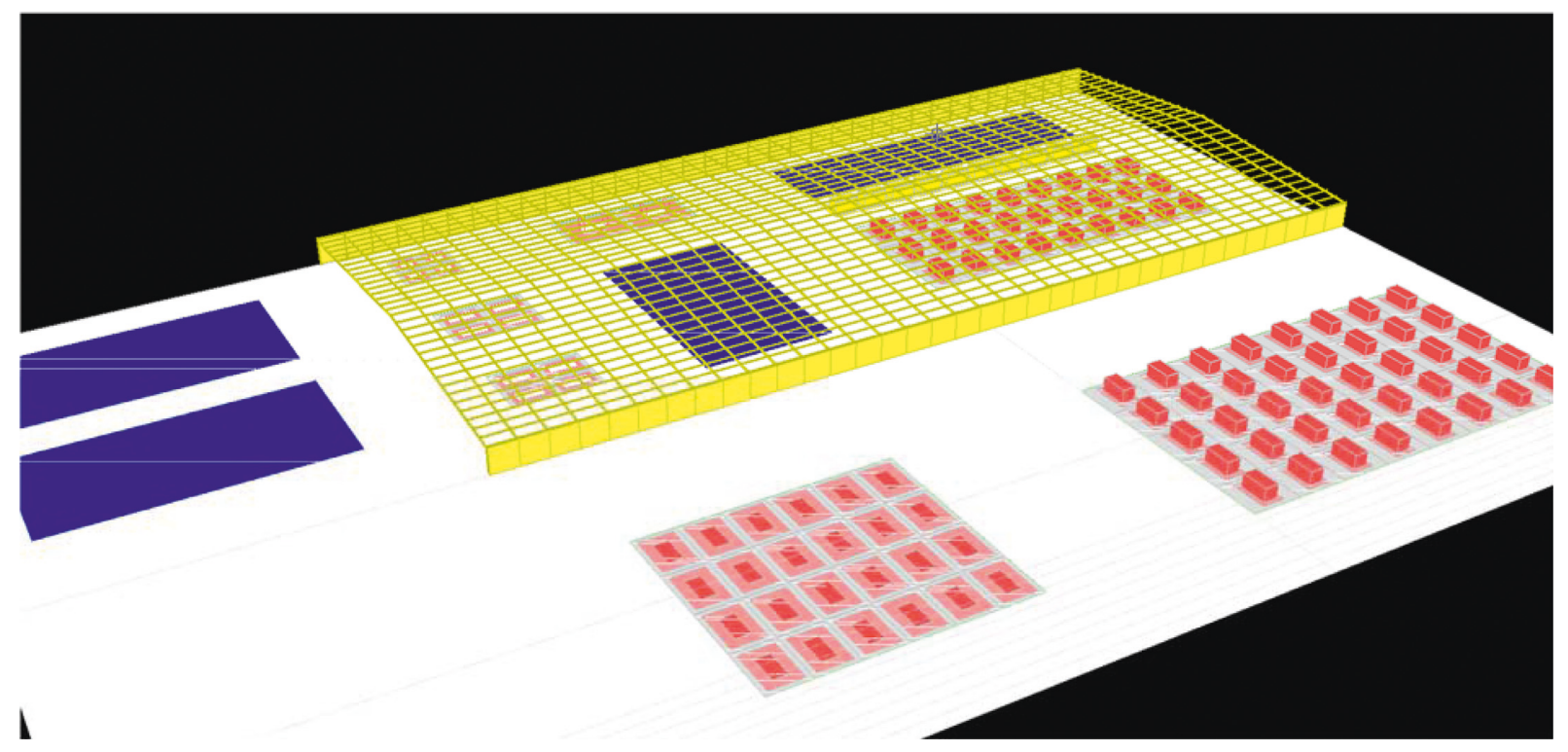

FIGURE 9: Simulation setup.

TABle 2: Productivity comparison between existing process and optimized process.

\begin{tabular}{|c|c|c|c|c|c|c|}
\hline \multirow{2}{*}{ Category } & \multirow{2}{*}{$\#$} & \multicolumn{2}{|c|}{ Existing } & \multicolumn{2}{|c|}{ Optimized } & \multirow{2}{*}{ Remark and optimization plan } \\
\hline & & Time $(\min )$ & Manpower & Time $(\min )$ & Manpower & \\
\hline \multirow{11}{*}{ Prestation } & PS-OS-2 & 60 & 3 & 60 & 3 & \multirow{11}{*}{$\begin{array}{c}\text { Downsize manpower } \\
\text { Add manpower } \\
\text { Add manpower }\end{array}$} \\
\hline & PS-M-1 & 60 & 1 & 60 & 1 & \\
\hline & PS-M-2 & 60 & 1 & 60 & 1 & \\
\hline & PS-A-F-1 & 180 & 2 & 60 & 6 & \\
\hline & PS-A-F-2 & 120 & 2 & 60 & 4 & \\
\hline & PS-A-F-3 & 60 & 3 & 60 & 3 & \\
\hline & PS-A-W-1 & 60 & 2 & 60 & 2 & \\
\hline & PS-A-C-1 & 15 & 2 & 15 & 2 & \\
\hline & PS-A-C-2 & $120^{*}$ & 2 & 240 & 1 & \\
\hline & PS-MA-1 & $120^{*}$ & 4 & 60 & 8 & \\
\hline & PS-MA-2 & $120^{*}$ & 1 & 60 & 2 & \\
\hline \multirow{11}{*}{ Station } & S-1 & 130 & 2 & 60 & 4 & Add manpower \\
\hline & S-2 & $120^{*}$ & 2 & 60 & 4 & Add manpower \\
\hline & S-3 & $90^{*}$ & 2 & 60 & 3 & Add manpower \\
\hline & S-4 & $90^{*}$ & 2 & 60 & 3 & Add manpower \\
\hline & S-5 & $120^{*}$ & 2 & 60 & 4 & Add manpower \\
\hline & S-6 & $80^{*}$ & 2 & \multirow[t]{2}{*}{60} & \multirow[t]{2}{*}{4} & \multirow[t]{2}{*}{ Integrate process } \\
\hline & S-7 & $50^{*}$ & 2 & & & \\
\hline & S-8 & $120^{*}$ & 2 & 60 & 4 & Add manpower \\
\hline & S-9 & $120^{*}$ & 2 & 60 & 4 & Add manpower \\
\hline & S-10 & 130 & 2 & 60 & 4 & Add manpower \\
\hline & S-S-1 & $120^{*}$ & 1 & 120 & 1 & \\
\hline \multirow{7}{*}{ Poststation } & WP-1 & 60 & 1 & 60 & 1 & \\
\hline & WP-2 & 30 & 2 & 30 & 2 & \\
\hline & WP-3 & 90 & 1 & 90 & 1 & \\
\hline & WP-4 & 60 & 1 & 60 & 1 & \multirow{4}{*}{ Add manpower } \\
\hline & WP-5 & 30 & 3 & 30 & 3 & \\
\hline & EP-1 & 240 & 1 & 60 & 4 & \\
\hline & EP-2 & 60 & 4 & 60 & 4 & \\
\hline \multicolumn{2}{|c|}{ Manpower $*$ Total time } & \multicolumn{2}{|c|}{5710} & \multicolumn{2}{|c|}{5070} & $11.2 \%$ reduction \\
\hline
\end{tabular}

PS : prestation, $\mathrm{S}$ : station, OS : outsourcing, M : member, A: assemble, F : floor, W : wall, C : celling, MA : modular assemble, WP: wet process, EP : end process.

hours, and materials according to the associated processes. A total of 5,710 minutes were required to manufacture a single modular unit. The main problem of the modular manufacturing process was the inefficient workforce management. Manpower arrangements were inconsistent with the manufacturing requirements and caused the 
TABle 3: Productivity comparison.

\begin{tabular}{lcc}
\hline Category & Existing process & Optimized process \\
\hline Days spent manufacturing (days) & 32 & 24 \\
Daily average manpower input (number of workers) & 9.37 & 10.82 \\
Daily average labor cost input (KRW) & $1,176,180$ & $1,009,511$ \\
Total manpower input (number of workers) & 299.81 & 259.57 \\
Total labor cost input (KRW) & $37,637,768$ & $32,304,364$ \\
\hline
\end{tabular}

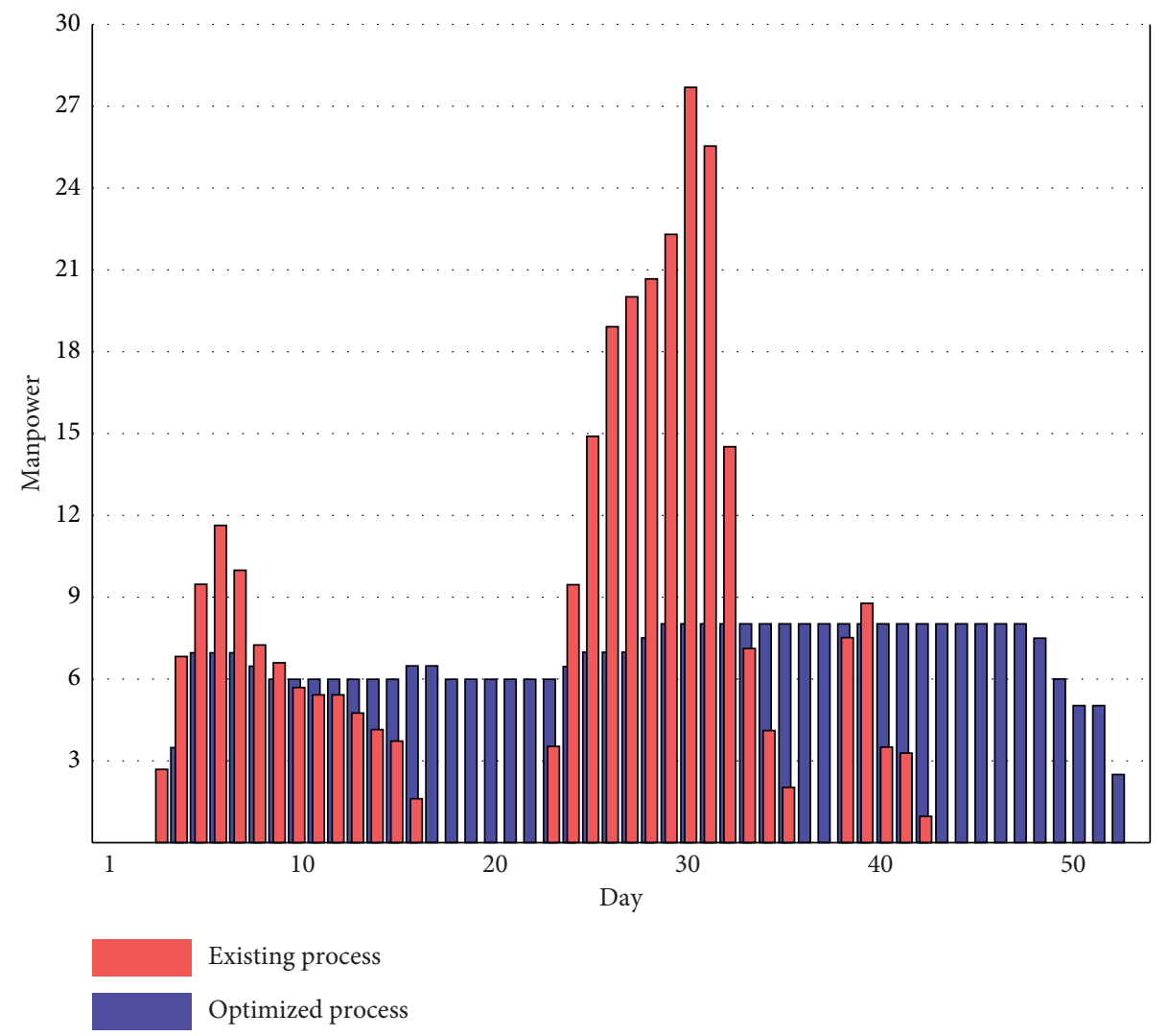

FIGURE 10: Manpower comparison between existing and optimized processes.

manufacturing process durations to be irregular, which delayed the entire process. To resolve this problem, subassembly lines were added and manpower was increased in addition to work integration and subdivision, contrary to the strategy used in a typical on-site construction scenario. However, there is no way to predict the effect of this change prior to implementation. To resolve this issue, this research utilized information and data related to modular factory manufacturing and identified the productivity of the current process. An integrated management system was developed with three overall functions: factory setup, project creation, and result analysis. Using this integrated management system, existing conditions were changed (e.g., change of process, change of manpower, and fluctuation of process arrangement) to create an optimized process. Subsequently, the integrated management system was refined to enable simulation through the system. This study configured a modular assembly process for manufacturing a total of thirty modular units in the developed program. In order to draw comparisons between possible processes, a process integrating manpower rearrangement was created through the integrated management system. If the manufacturing times are compared using the product of manpower input and time, the alternative manufacturing process requires 5,070 minutes, which is a $11.2 \%$ decrease in manufacturing time.

We developed an integrated management system that can manage the process, manpower, and materials for manufacturing modular components and assembling a finished module. Through the integrated management system, we can compare alternatives and design an optimized process. This integrated management system is being continuously developed and expanded to include a process rate management function and process table creation function in the future. Moreover, there are plans to add an optimization function that can automatically derive alternatives.

\section{Data Availability}

The data used to support the findings of this study are included within the article. 


\section{Conflicts of Interest}

The authors declare that they have no conflicts of interest regarding the publication of this paper.

\section{Acknowledgments}

This research was supported by grant no. 19RERP-B08288406 from the Housing Environment Research Program funded by the Ministry of Land, Infrastructure and Transport of the Korean government.

\section{References}

[1] K. R. Kim, M. S. Kim, H. Mon, H. K. Jang, and M. S. Choi, Implementation of Government Contracts and Improvement of Management Efficiency, Korea Institute of Public Finance, Yeongi-gun, Korea, 2017.

[2] T. H. Ha, B. H. Cho, H. J. Kim, and D. J. Kim, "Development of and efficient steel beam section for modular construction based on six sigma," Advances in Materials Science and Engineering, vol. 2016, Article ID 9687078, 13 pages, 2016.

[3] J. M. Schoenborn, "A case study approach to identifying the constraints and barriers to design innovation for modular construction," Master's thesis, Virginia Polytechnic Institute and State University, Blacksburg, VA, USA, 2012.

[4] B. H. Cho, H. J. Kim, and G. H. Ko, "The state of art in the modular construction in Korea," Journal of Korean Society of Steel Construction, vol. 19, no. 1, pp. 112-119, 2007.

[5] W. Shahzad, J. Mbachu, and N. Domingo, "Marginal productivity gained through prefabrication: case studies of building projects in Auckland," Buildings, vol. 5, no. 1, pp. 196-208, 2015.

[6] J.-D. Bang, C.-Y. Chun, J.-Y. Park, J.-Y. Kim, G.-D. Kim, and Y.-S. Chun, "An economic analysis of steel framed modular housing: compared with case of urban type living housing of wall-slab," LHI Journal of Land, Housing, and Urban Affairs, vol. 5, no. 4, pp. 305-314, 2014.

[7] A. A. Hammad, M. Hastak, and M. Syal, "Comparative study of manufactured housing production systems," Journal of Architectural Engineering, vol. 10, no. 4, pp. 136-142, 2004.

[8] O. Senghore, M. Hastak, T. S. Abdelhamid, A. AbuHammad, and M. G. Syal, "Production process for manufactured housing," Journal of Construction Engineering and Management, vol. 130, no. 5, pp. 708-718, 2004.

[9] N. Mehrotra, M. Syal, and M. Hastak, "Manufactured housing production layout design," Journal of Architectural Engineering, vol. 11, no. 1, pp. 25-34, 2005.

[10] D. Banerjee, M. Syal, and M. Hastak, "Material flow-based facility layout analysis of a manufactured housing production plant," Journal of Architectural Engineering, vol. 12, no. 4, pp. 196-206, 2006.

[11] M. A. Mullens, Factory Design for Modular Homebuilding, Constructability Press, Winter Partk, FL, USA, 2011.

[12] M. Mullens, "Innovation in the U.S. Industrialized housing industry: a tale of two strategies," International Journal for Housing Science and Its Application, vol. 32, no. 3, pp. 163178, 2008.

[13] I. Nahmens and M. Mullens, "The impact of product choice on lean homebuilding," Construction Innovation, vol. 9, no. 1, pp. 84-100, 2009.

[14] KICT, Technical Development of Modular Construction in Mid-High Rise Building and Higher Productivity, Korea
Institute of Civil Engineering and Building Technology, Goyang, Korea, 2014.

[15] T. Y. Kim, M. S. Park, H. S. Lee, S. W. Suh, J. H. Lee, and S. Y. Kim, "Optimization methodology of modular unit factory production process using DSM," Journal of Architectural Institute of Korea, vol. 29, no. 6, pp. 113-122, 2013.

[16] A. A. Hammad, "Simulation Model for Manufactured Housing Process," Master's thesis, Department of Civil and Environmental Engineering, University of Cincinnati, Cincinnati, OH, USA, 2001.

[17] A. A. Hammad, O. Salem, M. Hastak, and M. Syal, "Decision support system for manufactured housing facility layout," Journal of Architectural Engineering, vol. 14, no. 2, pp. 36-46, 2008. 


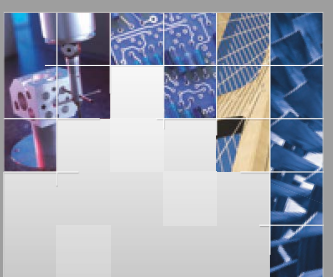

\section{Enfincering}
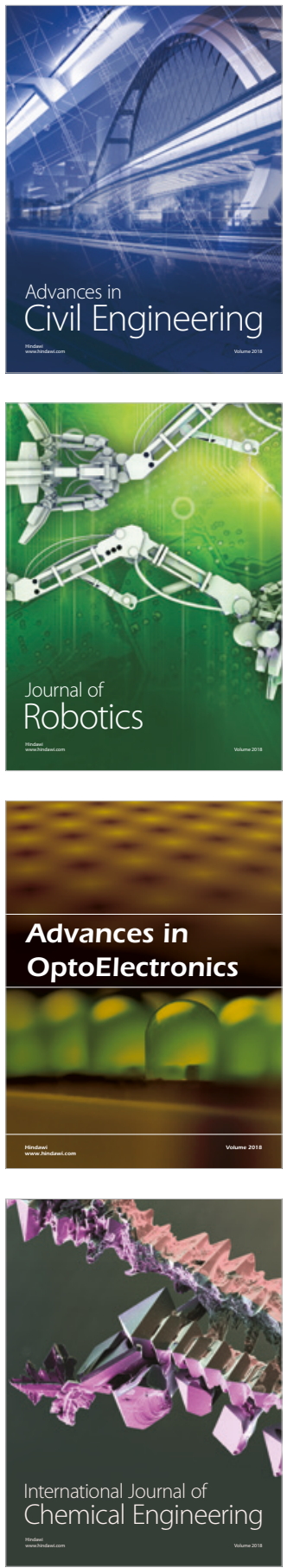

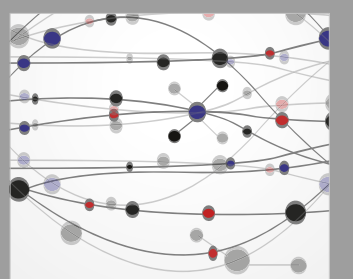

\section{Rotating \\ Machinery}

The Scientific World Journal



Submit your manuscripts at

www.hindawi.com

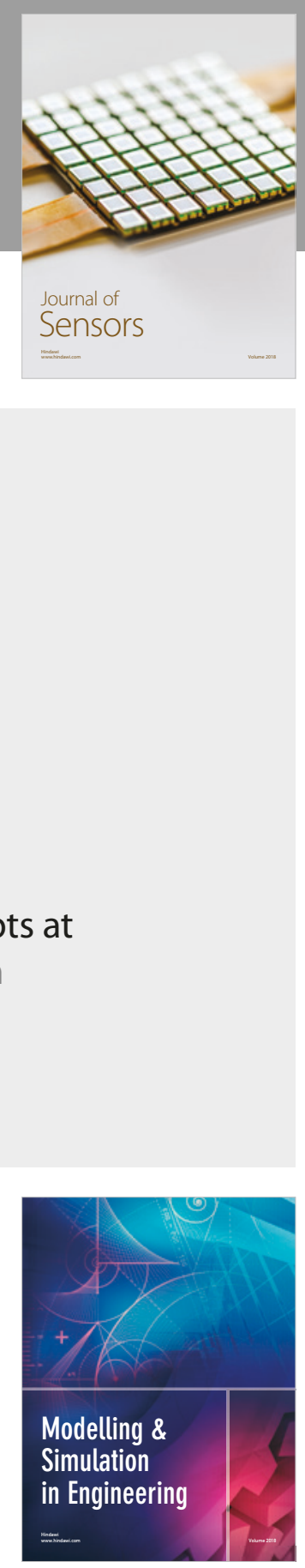

\section{Advances \\ Multimedia}
